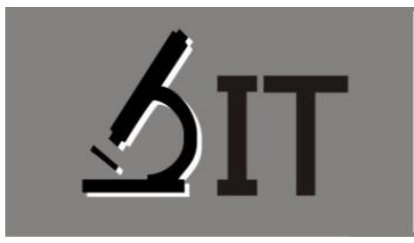

p-ISSN : 2597-8977

e-ISSN : $2597-8985$

Siska Sulistiani *) Prodi Pendidikan IPA

Ramlawat

Universitas Negeri Makassa

Sitti Rahma Yunus

Universitas Negeri Makassar

\section{PENGARUH REWARD AND PUNISHMENT SCORE DALAM \\ PEMBELAJARAN KOOPERATIF TIPE TAI (TEAM \\ ASSISTED INDIVIDUALIZATION) TERHADAP HASIL BELAJAR PESERTA DIDIK KELAS VII}

*) Correspondence Author: ikkasiskasulis@gmail.com
Abstrak: Penelitian ini bertujuan untuk mengetahui; (1) Peningkatan hasil belajar peserta didik kelas VII MTs Guppi Salotungo yang diajar dengan pemberian Reward and Punishment Score pada model kooperatif tipe TAI; (2) Peningkatan hasil belajar peserta didik kelas VII MTs Guppi Salotungo yang diajar model kooperatif tipe TAI; (3) Pengaruh pemberian Reward and Punishment Score pada model kooperatif tipe TAl terhadap hasil belajar peserta didik kelas VII MTs Guppi Salotungo Kabupaten Soppeng. Penelitian ini merupakan penelitian Quasi-eksperiment dengan menggunakan desain penelitian Nonequivalen control group design. Populasi penelitian adalah seluruh peserta didik kelas VII MTs Guppi Salotungo. Pengambilan sampel melalui teknik Cluster Random Sampling sehingga terpilih kelas VII A sebagai kelas eksperimen dan kelas VII B sebagai kelas kontrol. Pengumpulan data dalam penelitian ini menggunakan tes hasil belajar yang diberikan sesudah pembelajaran. Data dianalisis dengan statistik deskriptif dan statistik inferensial. Hasil analisis deskriptif hasil belajar diperoleh skor rata-rata 24,93 dengan rerata N-Gain 0,72 tergolong ke dalam kategori tinggi dan skor rata-rata 21,36 dengan rerata $\mathrm{N}$-Gain 0,58 tergolong ke dalam kategori sedang pada kelas kontrol. Berdasarkan hasil analisis statistik inferensial dengan menggunakan uji-t hasil belajar peserta didik memperlihatkan Ho ditolak dan $\mathrm{H}_{\alpha}$ diterima. Sehingga dapat disimpulkan bahwa pemberian Reward and Punishment Score pada model kooperatif tipe TAI berpengaruh terhadap hasil belajar peserta didik kelas VII MTs Guppi Salotungo pada materi Interaksi Makhluk Hidup dengan Lingkungannya.

Kata Kunci: Reward and Punishment Score, Interaksi Makhluk Hidup dengan Lingkungannya, Hasil belajar.

Abstract: The purpose of this research is to; (1) know students learning outcome of class VII student of MTs Guppi Salotungo by guided reward and punishment score at TAl type of cooperative models; (2) know students learning outcome of class VII student of MTs Guppi Salotungo be guided without reward and punishment score at TAl type of cooperative models; (3) The influence of guided reward and punishment score at TAI type of cooperative models towards learning outcome of class VII student of MTs Guppi Salotungo. This study is Quasi eksperimen with research design Nonequivalen control grup design. The study population was all student of class VII MTs Guppi Salotungo. Sampling through cluster random sampling techniques so that the selected class VII A as an experimental class and class VII B as the control class. Collecting data in this study using a given achievement test before and after learning. Data were analyzed with descriptive and inferensial statistic, the results descriptive analysis learning outcomes obtained an average score of 24,93 
with a mean of $\mathrm{N}$-Gain is 0,72 classified into a higher category in experimental class and the average score 21,36 with a mean of $\mathrm{N}$-Gain is 0,58 classified into a medium category in control class. Based on the results of inferensial statistic analysis using the t-test on learning outcomes of students show Ho was reject and $\mathrm{Ha}$ was accept. So it can be concluded that use of reward and punishment score on cooperative type TAI influences to learning outcomes of class VII Students of MTs Guppi Salotungo Study on interaction of living things with the environment.

Keywords: : Reward and punishment score, Living and Environment Interaction, Learning Outcomes.

\section{PENDAHULUAN}

IPA didefinisikan sebagai pengetahuan yang diperoleh melalui pengumpulan data dengan eksperimen, pengamatan, dan deduksi untuk menghasilkan suatu penjelasan tentang sebuah gejala yang dapat dipercaya. Secara umum IPA di SMP/MTS, meliputi bidang kajian energi dan perubahannya, bumi antariksa, mahluk hidup dan proses kehidupan, dan materi dan sifatnya yang sebenarnya sangat berperan dalam membantu peserta didik untuk memahami fenomena alam. IPA merupakan pengetahuan ilmiah, yaitu pengetahuan yang telah mengalami uji kebenaran melalui metode ilmiah, dengan ciri: objektif, metodik, sistematis, universal, dan tentatif (Trianto, 2010).

Hingga saat ini masih banyak peserta didik yang kurang tertarik pada IPA, hal ini berdasarkan wawancara yang telah dilakukan kepada beberapa peserta didik di MTs Guppi Salotungo kelas VII bahwa mereka kurang tertarik kepada IPA karena menganggap IPA sebagai mata pelajaran yang susah untuk dipahami. Dari observasi diketahui nilai rata-rata ulangan harian peserta didik pada mata pelajaran IPA masih banyak yang belum tuntas, yaitu $<75$. Selain itu Berdasarkan wawancara yang dilakukan kepada guru mata pelajaran IPA bahwa peserta didik mengikuti pelajaran dengan baik jika guru memberitahu sebelumnya bahwa akan diadakan tes yang akan diambil nilainya. Dengan kata lain, peserta didik akan giat belajar jika guru menginginkan tugas dikumpulkan atau guru akan mengadakan ulangan harian, sehingga secara tidak langsung peserta didik akan termotivasi dalam belajar.

Menanggapi peserta didik yang hanya mau belajar ketika ada ulangan seperti ini seorang guru dituntut untuk pandai dan berpikir kreatif dalam menetukan metode dan cara dalam melaksanakan tugas mengajar peserta didik supaya tercapai dan terpenuhi apa yang menjadi tujuan pembelajaran. Salah satunya adalah dengan memberikan kuis.

Pemberian kuis bisa berupa pilihan ganda atau uraian (essay). Menurut Arikunto (2012), Multiple choice test terdiri atas suatu keterangan atau pemberitahuan tentang suatu pengertian yang belum lengkap. Dan untuk melengkapinya harus memilih satu dari beberapa kemungkinan jawaban yang telah disediakan. Sedangkan tes bentuk esai adalah sejenis tes kemajuan belajar yang memerlukan jawaban yang bersifat pembahasan atau uraian kata-kata. Berdasarkan hasil wawancara dari beberapa peserta didik di MTs Guppi Salotungo yang menyatakan bahwa mereka lebih menyukai soal pilihan ganda karena jawaban telah tersedia. Namun di sisi lain dengan tersedianya jawaban akan memudahkan peserta didik untuk bisa menebak jawaban tanpa resiko apapun, mencontek dan melakukan kerjasama sesama teman.

Menurut Slamet (2014), kebiasaan buruk peserta didik menebak, mencontek, dan kerjasama menjawab soal perlu diatasi. Sehingga untuk mengatasi masalah tersebut diperlukan inovasi baru yaitu memberikan hukuman (punishment) pada peserta didik yang melakukan kebiasaan buruk tersebut dan memberikan hadiah (reward) kepada peserta didik yang tidak melakukan hal tersebut atau peserta didik yang telah melakukan hal yang benar. Namun pemberian reward dan punishment 
pada peserta didik tidak boleh sembarangan, untuk itu sebaiknya reward dan punishment diberikan dalam bentuk skor pada penskoran butir-butir soal tes yang diberikan. Karena setiap kuis diterapkan penambahan dan pengurangan skor, maka kelompok yang memiliki skor tertinggi akan diberikan reward lagi berupa pulpen, buku, atau semacamnya. Jadi pemberian reward score and punishment score ini juga sebagai acuan untuk mendapatkan reward selanjutnya. Pemberian reward seperti ini dapat meningkatkan hasil belajar peserta didik.

Selain untuk mengurangi kebiasaan buruk peserta didik, pemberian reward score (penambahan skor) dan punishment score (pengurangan skor) juga bisa meningkatkan motivasi belajar dan kepercayaan diri peserta didik dalam pembelajaran. Banyak dampak positif dalam pembelajaran dengan diberikannya reward yaitu hubungan guru dan peserta didik menjadi lebih erat, perhatian peserta didik pada IPA lebih meningkat, merangsang dan meningkatkan motivasi belajar IPA, meningkatkan kegiatan belajar IPA, dan membina tingkah laku peserta didik yang produktif. Sementara dampak pemberian punishment adalah menyadarkan peserta didik akan kesalahannya sehingga mereka akan termotivasi untuk jadi lebih baik (Slamet, 2014).

Penyebab rendahnya hasil belajar juga disebabkan oleh keaktifan peserta didik dalam proses pembelajaran. Hal ini berdasarkan wawancara pada guru mata pelajaran IPA MTs Guppi Salotungo, bahwa keaktifan peserta didik dalam pembelajaran tergantung pada materi yang dibawakan oleh gurunya selain itu model yang diterapkan oleh pendidik juga berpengaruh pada keaktifan peserta didik

Sehubungan dengan hal tersebut, model pembelajaran yang dapat meningkatkan keaktifan serta dapat pula meningkatkan hasil belajar peserta didik adalah model pembelajaran kooperatif dengam metode TAI (Team Assisted Individualization). Menurut Slavin (Alsa, 2011), Metode belajar T.A.I. pada dasarnya adalah metode Cooperative Learning. Pada metode ini pembelajaran dilakukan dengan membagi peserta didik menjadi tiga atau empat kelompok belajar yang disusun berdasar kemampuan campuran (kemampuan anggota dalam satu kelompok adalah heterogen). Sesama anggota kelompok saling membantu satu sama lain, saling mengoreksi, dan saling memberi semangat untuk bekerja secara cepat dan akurat. Rewards diberikan kepada tim berdasar atas benar dan banyaknya tugas yang diselesaikan anggota tim secara keseluruhan.

Reward dalam Kamus Bahasa Inggris-Indonesia (2016) diartikan dengan ganjaran dan hadiah, upah dan pahala, membalas dan memberi penghargaan. Menurut Mulyasa (Rosyid, 2018) reward adalah respon terhadap suatu tingkah laku yang dapat meningkatkan kemungkinan terulang kembalinya tingkah laku tersebut.

Sedangkan menurut Arikunto (1993) reward merupakan suatu yang disenangi dan digemari oleh anak-anak yang diberikan kepada siapa yang dapat memenuhi harapan yakni mencapai tujuan yang ditentukan atau bahkan melebihinya. Dalam memberikan reward, seorang peserta didik harus menyesuaikan dengan perbuatan-perbuatan atau pekerjaan peserta didik dan jangan sampai menebalkan sifat materialis pada peserta didik, kemudian guru juga harus menghilangkan anggapan anak didik terhadap upah atau balas jasa atas perbuatan yang dilakukan.

Jadi reward adalah penghargaan atau hadiah yang diberikan oleh seseorang guru kepada seseorang atau kelompok tertentu (peserta didik). Reward diberikan kepada peserta didik yang berhasil (mampu mengerjakan soal dengan baik). Reward yang diberikan itu merupakan sesuatu yang menyenangkan atau yang digemari oleh peserta didik, bisa berupa benda konkrit atau abstrak, misalnya pujian, perhatian, penghargaan, dan lain-lain. Secara kongkret ganjaran atau reward dalam pendidikan tidak hanya berupa materi, apresiasi yang baik juga merupakan reward yang bernilai tinggi.

Dalam penelitian ini yang dimaksud dengan reward score adalah skor lebih yang diberikan kepada peserta didik yang bisa menjawab soal atau tes yang diberikan sebagai suatu penghargaan. Pemberian angka atau skor ini dimaksudkan agar peserta didik bisa lebih semangat atau termotivasi untuk belajar, karena biasanya angka merupakan motivasi yang kuat bagi peserta didik. Oleh karena 
itu, pemberian angka atau skot disebut reward karena dapat membangkitkan motivasi peserta didik.

Menurut Santoso (2011), model punishment score merupakan model penskoran yang memperhitungkan jawaban salah yang direspon peserta tes dengan jalan memberi hukuman dalam bentuk pengurangan skor. Algina Menyebutnya juga dengan nama right minus wrongs correction. Asumsi dasar dari penggunaan rumus ini adalah jawaban salah merupakan hasil tebakan, sehingga jumlah yang salah dibagi dengan k-1 merupakan hukuman bagi peserta tes yang menjawab dengan tebakan.

Teknik penskoran penalti (punishment score) adalah penskoran yang mengurangi skor total jawaban benar dengan jumlah jawaban salah. Penilaian penalti dilakukan karena pada tes pilihan ganda memungkinkan siswa untuk menebak ketika memilih pilihan jawaban. Siswa yang tidak mengetahui jawaban yang benar cenderung melakukan tebakan. Dengan menebak pilihan jawaban yang disediakan maka siswa memiliki peluang cukup besar untuk dapat menjawab butir soal dengan benar dibandingkan bila jawaban ditinggalkan kosong akan membuat peluang siswa mendapatkan skor sama sekali tidak ada. Karena alasan itu maka penskoran secara penalti diterapkan pada tes pilihan ganda.. Pengalaman di lapangan, penyebab siswa melakukan tebakan adalah karena kemampuan siswa yang tidak dapat menemukan jawaban sehingga sampai waktu mengerjakan tes hampir habis masih banyak jawaban yang belum diisi, maka siswa cenderung akan mengisi dengan cara menebak agar seluruh jawaban dapat terisi (Khaeruddin, 2016).

Menurut Suprihatiningrum (2016), model pembelajaran kooperatif tipe TAI ini menekankan bahwa individu yang belum memahami materi merupakan tanggung jawab anggota kelompok lain sehingga anggota yang sudah paham perlu memberikan bantuan kepada anggota yang belum paham. Dengan demikian, secara ringkas model ini, sebagai berikut. (1) Pembentukan kelompok atas dasar heterogenitas, (2) Pemberian bahan ajar, dapat berbentuk modul atau LKS, (3) Pembelajaran dalam kelompok, peserta didik yang belum paham dibantu oleh peserta didik yang pandai dalam satu kelompok secara individual atau dapat dikatakan dilakukan peer tutor, (4)Pengerjaan kuis atau ujian, (5) Refleksi dan umpan balik dari guru.

Dalam hal ini pemberian punishment dimaksudkan untuk memperbaiki dan menyadarkan peserta didik pada kesalahan yang diperbuatnya pada ssat menjawab soal-soal yang diberikan kepadanya, sehingga peserta didik berjanji pada dirinya sendiri tidak akan mengulangi kesalahan yang serupa. Punishment score berupa pengurangan atau pemberian nilai minus kepada peserta didik yang salah dalam menjawab soal atau tes yang diberikan. Hal ini dimaksudkan agar peserta didik lebih hati-hati dalam menjawab suatu permasalahan yang ada, tidak hanya asal tebak dalam memilih jawaban.

Adapun jurnal relevan yang didapatkan berdasarkan masalah tersebut yaitu hasil penelitian Slamet (2014) menyatakan bahwa terdapat pengaruh bentuk tes formatif asosiasi pilihan ganda dengan reward and punishment score terhadap hasil belajar peserta didik. Rata-rata skor ideal hasil belajar adalah 19. Rata-rata skor hasil belajar siswa kelas eksperimen adalah 11,950 atau 62,895\% sedangkan rata-rata skor hasil belajar siswa kelas kontrol adalah 10,650 atau 56,053\%. Perbedaan rata-rata skor hasil belajar siswa kelas eksperimen dan kontrol yaitu 1,300 atau 6,842\%. Hasil penelitian lainnya ialah Bhakti (2015) pada umumnya siswa yang dikoreksi dengan model penskoran penalti dan penskoran kompensasi menunjukkan hasil lebih akurat sesuai dengan kemampuannya dan jawaban mereka mencerminkan kemampuan mereka. Model penskoran penalty (Punishment score) dan penskoran kompensasi (reward score) akan membuat siswa hati-hati dan membatasi tidak melakukan tebak acak terhadap butir-butir soal yang diberikan.

Hasil penelitian dari jurnal yang relevan yang telah dilakukan oleh beberapa peneliti sebelumnya dapat dijadikan acuan, maka calon peneliti akan mencoba meneliti mengenai pengaruh Reward and Punishment Score pada Pembelajaran Kooperatif Tipe TAI Terhadap Hasil Belajar Peserta Didik Kelas VII MTs Guppi Salotungo Kabupaten Soppeng 
Berdasarkan latar belakang tersebut, maka tujuan pada penelitian ini adalah sebagai berikut: 1) Untuk mengetahui peningkatan hasil belajar IPA peserta didik kelas VII MTs Guppi Salotungo yang diberikan reward and punishment score pada pembelajaran kooperatif tipe TAI (Team Asisted Individualization).

2) Untuk mengetahui peningkatan hasil belajar IPA peserta didik kelas VII MTs Guppi Salotungo yang diajar dengan model pembelajaran kooperatif tipe TAI (Team Asisted Individualization).

3) Pengaruh pemberian reward and punishment score pada pembelajaran kooperatif tipe TAI (Team Asisted Individualization) terhadap hasil belajar IPA peserta didik kelas VII MTs Guppi Salotungo kabupaten Soppeng pada semester genap tahun ajaran 2018/2019.

\section{METODE}

Penelitian ini merupakan penelitian Quasi-eksperimental yang dilakukan untuk meningkatkan hasil belajar peserta didik. Penelitian ini terdiri dari dua kelas, yaitu kelas eksperimen dan kelas kontrol. Pada kelas eksperimen diberikan pengajaran dengan peneraparn Reward and Punishment Score sedangkan kelas kontrol tanpa penerapan Reward and Punishment Score dengan model pembelajaran yang sama yaitu model kooperatif tipe TAl.

Penelitian ini dilaksanakan di MTs Guppi Salotungo Kabupaten Soppeng yang beralamatkan di J. Salotungo.Waktu penelitian dilakukan pada semester genap selama 5 kali pertemuan. Populasi dalam penelitian ini ialah seluruh peserta didik kelas VII MTs Guppi Salotungo pada tahun ajaran 2018/2019 yang terdiri dari 3 kelas dengan jumlah peserta didik keseluruhan sebanyak 54 orang. Pengambilan sampel dipilih secara cluster random sampling dimana tekhnik ini digunakan untuk populasi yang terdiri atas kelompok-kelompok. Atas dasar tersebut pendidik dari sekolah memberikan dua kelas yang akan dijadikan sebagai sampel penelitian yaitu kelas VII A sebagai kelas eksperimen yaitu kelas yang menggunakan reward and punishment score dengan jumlah peserta didik 18 orang sedangkan kelas VII B sebagai kelas kontrol yaitu kelas yang tanpa menggunakan reward and punishment score dengan jumlah peserta didik 17 orang.

Penelitian ini menggunakan desain penelitian Pretest Postest Nonequivalent Control Grup Design. Data hasil belajar peserta didik diperoleh melalui pemberian tes hasil belajar kognitif yang dibuat dalam bentuk pilihan ganda sebanyak 30 butir soal yang diberikan saat pretest dan posstest. Soal yang diberikan masing-masing sama untuk kelas kontrol dan kelas eksperimen. Bentuk soal dalam tes hasil belajar berada pada tingkatan C1 sampai C4 sesuai dengan ranah kognitif KD yang digunakan.

Data yang diperoleh dari sampel penelitian ini berupa data kuantitatif. Hasil penelitian meliputi tes hasil belajar peserta didik yang diolah menggunakan dua teknik statistik yaitu statistik deskriptif dan statistik inferensial.

Statistik deskriptif berfungsi untuk mendeskripsikan objek yang diteliti melalui data sampel. Analisis ini bertujuan untuk mendeskripsikan peningkatan motivasi dan hasil belajar peserta didik untuk kelas eksperimen yang terdiri atas skor rata-rata (mean), skor deviasi, varians, skor tertinggi dan skor terendah.

\section{HASIL DAN PEMBAHASAN}

\section{Hasil Penelitian}

Statistik deskriptif digunakan untuk mendeskripsikan hasil belajar peserta didik yang diperoleh setelah mengikuti proses pembelajaran menggunakan Reward and Punishment Score. Hasil analisis deskriptif skor hasil belajar peserta didik pada Tabel 1. 
Tabel 1. Statistik Data Skor Hasil Belajar Peserta Didik Kelas Eksperimen dan Kelas Kontrol

\begin{tabular}{cccccc}
\hline \multirow{2}{*}{ No. } & Statistik & \multicolumn{2}{c}{ Kelas Eksperimen } & \multicolumn{2}{c}{ Kelas Kontrol } \\
\cline { 3 - 6 } & & Pretest & Posttest & Pretest & Posttest \\
\hline 1. & Jumlah Sampel & 15 & 15 & 14 & 14 \\
2. & Skor Tertinggi & 18 & 29 & 14 & 25 \\
3. & Skor Terendah & 6 & 21 & 5 & 16 \\
4. & Skor Rata-rata & 13,8 & 24,93 & 8,92 & 21,36 \\
5. & Std. Deviasi & 3,83 & 2,01 & 2,60 & 3,21 \\
6. & Varians & 13,76 & 5,44 & 6,53 & 9,55 \\
\hline
\end{tabular}

Berdasarkan Tabel 1 menunjukkan bahwa hasil pretest hasil belajar IPA pada kelas eksperimen yang merupakan kelas yang diberikan perlakuan, diperoleh skor rata-rata peserta didik 13,8 dengan standar deviasi 3,83. Skor tertinggi yang diperoleh 18 dan skor terendah 6 dengan skor total tertinggi yaitu 30 .

Sedangkan hasil pretest hasil belajar IPA pada kelas kontrol yang merupakan kelas yang tidak diberikan perlakuan, diperoleh skor rata-rata peserta didik 8,92 dengan standar deviasi 2,60. Skor tertinggi yang diperoleh 14 dan skor terendah 5 dengan skor total tertinggi yaitu 30.

Hasil posttest hasil belajar IPA pada kelas eksperimen, diperoleh skor rata-rata peserta didik 24,93 dengan standar deviasi 2,01. Skor tertinggi yang diperoleh 29 dan skor terendah 21 dengan skor total tertinggi yaitu 30. Sedangkan hasil posttest hasil belajar IPA pada kelas kontrol, diperoleh skor rata-rata peserta didik 21,36 dengan standar deviasi 3,21. Skor tertinggi yang diperoleh 25 dan skor terendah 16 dengan skor ideal yaitu 30.

Pengkategorian hasil belajar peserta didik berdasarkan skor Rerata N-gain yang diperoleh dikedua kelas seperti pada Tabel berikut:

Tabel 2. Kategori N-Gain Hasil Belajar

\begin{tabular}{|c|c|c|c|c|}
\hline \multirow{2}{*}{ Kelas } & \multicolumn{2}{|c|}{ Skor } & \multirow{2}{*}{ Rata-Rata Skor N-Gain } & \multirow{2}{*}{ Kategori } \\
\hline & Pre-Test & Post-Test & & \\
\hline Kelas Eksperimen & 13,6 & 24,9 & 0,72 & Tinggi \\
\hline Kelas Kontrol & 9,2 & 21,1 & 0,58 & Sedang \\
\hline
\end{tabular}

Berdasarkan Tabel 2 diperoleh skor Rata-rata N-gain hasil belajar peserta didik kelas eksperimen termasuk dalam kategori tinggi dengan skor $\mathrm{N}$-gain 0,72 sedangkan skor $\mathrm{N}$-gain hasil belajar peserta didik pada kelas kontrol termasuk dalam kategori sedang dengan skor N-gain 0,58.

Berdasarkan hasil analisis menunjukkan bahwa ada pengaruh hasil belajar peserta didik yang diajar dengan pemberian reward and punishment score pada model pembelajaran tipe TAI. Hal ini dapat dilihat dari analisis statistik deskriptif skor rata-rata posstest kelas eksperimen adalah 24,93 sedangkan pada kelas kontrol 21,36. Hasil analisis statistik deskriptif menggunakan rumus $\mathrm{N}$-gain diperoleh untuk kelas yang diajar dengan pemberian reward and punishment score pada pembelajaran kooperatif tipe TAI tergolong dalam kategori tinggi yaitu 0,73 sedangkan pada kelas yang diajarkan model pembelajaran kooperatif tipe TAI tanpa reward and punishment score tergolong kategori sedang dengan skor 0,58. 
Tabel 3. Skor Kuis Kelas Eksperimen

\begin{tabular}{cccc}
\hline Kategori & Jumlah Peserta Didik & Rata-Rata Skor Kuis & $\begin{array}{c}\text { Rata-Rata Skor Hasil } \\
\text { Belajar }\end{array}$ \\
\hline Rendah & 0 & 0 & 0 \\
Sedang & 8 & 23,17 & 23,63 \\
Tinggi & 7 & 31,09 & 26,43 \\
\hline
\end{tabular}

Berdasarkan Tabel 3 pada kelas eksperimen dengan jumlah peserta didik sebanyak 15 orang yang diberi reward and punishment score. Sebanyak 7 orang peserta didik mendapat nilai skor kuis pada kategori tinggi dengan nilai rerata skor 31,09. Sedangkan peserta didik mendapat nilai skor kategori sedang dengan nilai rerata skor 23,17 sebanyak 8 orang. Dilihat dari tes hasil belajar (postest) peserta didik dengan nilai rerata skor kuis pada kategori tinggi memiliki nilai rerata postest sebesar 26,43. Dimana skor ini lebih tinggi dibandingkan dengan skor rata-rata posttest yaitu 24,93 . Sedangkan peserta didik dengan nilai rerata skor kuis pada kategori sedang memiliki nilai rerata posttest sebesar 23,63. Skor ini masuk ke dalam skor rata-rata.

Rata-rata skor ideal hasil belajar adalah 19. Rata-rata skor hasil belajar siswa kelas eksperimen adalah 11,950 atau $62,895 \%$ sedangkan rata-rata skor hasil belajar siswa kelas kontrol adalah 10,650 atau 56,053\%. Perbedaan rata-rata skor hasil belajar siswa kelas eksperimen dan kontrol yaitu 1,300 atau 6,842\%. Untuk memperkuat hasil analisis deskriptif, maka dilakukan analisis statistik inferensial untuk membuktikan hipotesis yang diajukan dengan menggunakan statistik uji-t. sebelum digunakan uji-t, terlebih dahulu di lakukan uji normalitas dan homogenitas. Uji normalitas data digunakan untuk menguji kenormalan data skor sedangkan uji homogenitas digunakan untuk menguji apakah homogen atau tidak. Data dapat dikatan homogen apabila $x^{2}$ hitung lebih kecil daripada $x^{2}$ tabel. Hasil uji normalitas kelas eksperimen dan kelas kontrol $x^{2}$ hitung lebih kecil daripada $x^{2}$ tabel. Berdasarkan hasil uji homogenitas data $x^{2}$ hitung lebih kecil daripada $x^{2}$ tabel untuk kedua kelas (kelas eksperimen dan kelas kontrol) hal ini berarti data untuk kelas eksperimen dan kontrol terdistribusi normal.

Hasil analisis inferensial dengan menggunakan uji-t diperoleh skor $t_{\text {hitung }}$ sebesar 5,54 lebih tinggi daripada skor $t_{\text {tabel }}$ yakni 1,35. Hal ini berarti $H_{0}$ ditolak dan $H_{\alpha}$ diterima. Sehingga dapat disimpulkan bahwa pemberian reward and punishment score pada pembelajaran kooperatif tipe TAI berpengaruh positif terhadap hasil belajar peserta didik kelas VII MTs Guppi Salotungo pada materi interkasi makhluk hidup dengan lingkungannya.

\section{Pembahasan}

Hasil penelitian menunjukkan bahwa pemberian reward and punishment score sangat mempengaruhi nilai individu dan nilai kelompok. Punishment score membuat peserta didik lebih berhati-hati dalam menjawab soal. Peserta didik yang tidak mengetahui dan tidak memiliki pengetahuan pada soal tersebut tidak akan menjawab soal karena khawatir jawabannya akan salah dan mengurangi nilai mereka. Semakin banyak soal yang dijawab salah semakin banyak pula skor mines yang didapatkan yang tentunya berpengaruh pada skor kelompoknya. Sehingga secara tidak langsung peserta didik harus lebih lagi belajar agar dapat menjawab soal dengan benar selain untuk nilai skor individu juga untuk skor kelompoknya.

Sejalan dengan penelitian Bhakti (2015) pada umumnya siswa yang dikoreksi dengan model penskoran penalti dan penskoran kompensasi menunjukkan hasil lebih akurat sesuai dengan kemampuannya dan jawaban mereka mencerminkan kemampuan mereka. Model penskoran penalty (Punishment score) dan penskoran kompensasi (reward score) akan membuat siswa hatihati dan membatasi tidak melakukan tebak acak terhadap butir-butir soal yang diberikan. Hasil 
penelitian yang lain Slamet (2014) menyatakan bahwa terdapat pengaruh bentuk tes formatif asosiasi pilihan ganda dengan reward and punishment score terhadap hasil belajar peserta didik.

Pemberian reward pada kelompok yang mempunyai nilai skor yang lebih tinggi dibanding yang lainnya membuat peserta didik lebih termotivasi dalam belajar. Peserta didik sangat antusias ketika hasil prestasi kelompok dibacakan didepan kelas. Pemberian reward mempengaruhi motivasi dalam belajar. Sebagaimana Hidayati (2016) menyatakan ada pengaruh pemberian reward terhadap motivasi belajar siswa. Pemberian pemberian reward terhadap motivasi belajar sangat kuat pengaruhnya. dengan motivasi belajar yang kuat makan hasil belajar juga akan meningkat. Hasil penelitian menunjukkan bahwa motivasi belajar mempengaruhi hasil belajar peserta didik. Sardiman (2016) menyatakan bahwa seseorang akan berhasil dalam belajar ketika memiliki motivasi dalam belajar.

Pembelajaran kooperatif tipe TAI dapat memberi kekuatan motivasi dan bantuan teman sekelompok sehingga jika ada kesulitan dalam pembelajaran ada teman yang dapat membantu memecahkan masalah. Penggunaan metode ini juga merupakan upaya dalam meningkatkan antusias siswa dalam pembelajaran, sehingga akan meningkatkan aktivitas siswa dalam pembelajaran karena kesulitan-kesulitan yang ada dalam pembelajaran akan didiskusikan dan dibantu pemecahannya oleh teman sekelompok. Sebagaimana Alsa (2011) menyatakan bahwa model TAl efektif meningkatkan prestasi belajar peserta didik metode belajar. T.A.l. tidak hanya efektif meningkatkan prestasi belajar matematika dan statistika saja, tapi juga efektif untuk meningkatkan prestasi belajar mata pelajaran lain, sepanjang karakteristik materinya dapat dirancang dalam bentuk tugas-tugas yang menciptakan iklim saling ketergantungan positif dan konstruktif di antara siswa, sehingga menuntut mereka harus bekerjasama secara optimal di dalam masing-masing kelompok belajar untuk mencapai tujuan atau target pembelajaran.

\section{KESIMPULAN}

Berdasarkan hasil penelitian dan pembahasan dapat disimpulkan sebagai berikut :

1. Peningkatan hasil belajar peserta didik kelas VII MTs Guppi Salotungo Kabupaten Soppeng yang diberi Reward and Punishment Score pada materi interaksi makhluk hidup dengan lingkungannya diperoleh skor rata-rata 24,93 dengan rerata N-Gain 0,72 berada pada kategori tinggi.

2. Peningkatan hasil belajar peserta didik kelas VII MTs Guppi Salotungo Kabupaten Soppeng yang diajar dengan model pembelajaran kooperatif tipe TAI (Team Assisted Individualization) pada materi interaksi makhluk hidup dengan lingkungannya diperoleh skor rata-rata 21,36 dengan rerata $\mathrm{N}$-Gain 0,58 berada pada kategori sedang.

3. Terdapat pengaruh pemberian Reward and Punishment Score pada pembelajaran kooperatif tipe TAI (Team Assisted Individualization) terhadap hasil belajar IPA peserta didik Kelas VII MTs Guppi Salotungo.

\section{DAFTAR PUSTAKA}

Alsa, Asmadi. (2011). Pengaruh Metode Belajar Team Assisted Individualization terhadap Prestasi Belajar Statistika pada Mahasiswa Psikologi. Jurnal Psikologi, Vol. 38, No. 1.

A. M, Sardiman. (2001). Interaksi dan Motivasi Belajar Mengajar. Jakarta: PT.Raja Grafindo persada Arikunto, Suharsimi. (1993). Manajemen Pengajaran. Jakarta: Rineka Cipta

Arikunto, Suharsimi. (2012). Dasar-Dasar Evaluasi Pendidikan Edisi 2. Bumi Aksara: Yogyakarta. Bhakti, Yoga Budi. (2015). Pengaruh Jumlah Alternatif Jawaban dan Teknik Penskoran Terhadap Reliabilitas Tes. Research and Development Journal of Education, Vol. 1, No. 2. 
Hidayati, Nurul dan Suharningsih. (2016). Pengaruh pemberian Reward Terhadap Motivasi Belajar Siswa Pada Kegiatan Pembelajaran PPKn kelas VIII di SMP Negeri 2 Krian. Kajian Moral dan Kewarganegaraan, Vol. 2, No. 4.

$\mathrm{KBBI}$ online. Kbbi.web.id

Kaeruddin. (2016). Teknik Penskoran Tes Obyektif Pilihan Ganda. Jurnal Madaniyah. Vol.2 Edisi 11. Rosyid, Moh. Zaiful,. \& Abdullah, Aminol Rosid. (2018). Reward \& Punishment dalam Pendidikan. Malang: Literasi Nusantara.

Santoso, Budi. (2011). Inappropriatness Score Based on Item Response Theory. Jurnal Evaluasi Pendidikan, Vol. 2, No. 2.

Slamet,. \& Maarif, Samsul. (2014). Pengaruh Bentuk Tes Formatif Assosiasi Pilihan Ganda dengan Reward dan Punisment Score pada Pembelajaran Matematika SMA. Jurnal IImiah Program Studi Matematika STKIP Bandung, Vol. 3, No. 1.

Sudjana, N. (2005). Metode Statistika. Bandung: PT. Tarsito.

Sugiyono. (2015). Metodeologi Penelitian. Bandung: Penerbit Alfabeta.

Sulistyaningsih., Eko., Ashadi., \& Setyowati, Widiastuti Agustina Eko. (2015). Penerapan Metode Pembelajaran Team Assisted Individualization (TAI) dilengkapi Catatan Terbimbing untuk Meningkatkan Aktivitas dan Prestasi Belajar Siswa Kelas XI MIA pada Materi Kesetimbangan Kimia di SMA Negeri 1 Sukoharjo Tahun Ajaran 2014/2015. Jurnal Pendidikan Kimia, Vol. 4, No. 2.

Suprihatiningrum, Jamil. (2016). Strategi Pembelajaran Teori \& Aplikasi. Yogyakarta: Ar-Ruzz Media Trianto. (2010). Mendesain Model Pembelajaran Inovatif-Progresif; Konsep, Landasan dan Implementasinya pada Kurikulum Tingkat Satuan Pendidikan (KTSP). Surabaya: Kencana Prenada Media Group.

\section{Siska Sulistiani \\ Mahasiswa Program Studi Pendidikan IPA FMIPA UNM, aktif melakukan penelitian pada bidang Pendidikan IPA, dapat dihubungi melalui pos-el: ikkasiskasulis@gmail.com.}

\section{Ramlawati}

Dosen Program Studi Pendidikan IPA FMIPA UNM, aktif melakukan penelitian pada bidang Pendidikan IPA.

\section{Sitti Rahma Yunus}

Dosen Program Studi Pendidikan IPA FMIPA UNM, aktif melakukan penelitian pada bidang Pendidikan IPA. 